\title{
Analysis on Public-Based Water Source Conservation (A Case Study in Insana Region, Timor Tengah Utara)
}

\author{
Emanuel M. Y. Hano' $e^{1}$, Bagyo Yanuwiadi ${ }^{2}$, Rudy Sulistyono ${ }^{3}$ \\ ${ }^{1}$ Post Graduate School of Environmental and Development, Brawijaya University, Malang, Indonesia \\ ${ }^{2}$ Department of Biology, Faculty of Science, Brawijaya University, Malang, Indonesia \\ ${ }^{3}$ Department of Agricultural Cultivation, Faculty of Agricultural Sciences, Brawijaya University, Malang, Indonesia
}

\begin{abstract}
Conservation refers to effort to explore and use natural resources wisely in order to maintain their value, quality and sustainability. Spring, an example of ground water resource, becomes major source of water for the society. Purpose of water source conservation is to maintain characteristics and function of water source, preserve environment around the water source and make sure there is ample supply of clean water now and in the future. Important aspect in water source management is participation from the society, public and private institution in water source conservation program. Efforts and appropriate water management systems to conserve water-use based on resources are more focused on determining the required components from upstream to downstream so that community-based water conservation concepts can be achieved well for sustainability for the benefit of society and environmental goals. The objectives of the study were to analyze 1) public participation, and 2) strategies for public-based water source conservation in Insana region. The study was descriptive quantitative study. Arstein ladder was used to identify public participation and SWOT analysis was used to develop the strategy. The results of the analysis show that based on the Arstein ladder, the public participation was categorized as informing. Furthermore, based on the SWOT analysis, the water source conservation strategies were conducting conservation program, minimizing social conflict, establishing regulations on conservation areas and water source preservation, conducting human resource development program for the locals.
\end{abstract}

Keywords: Conservation, Insana Region, Public Participation, Water Source

\section{INTRODUCTION}

Water forms the basis of all life on the Earth and is the foremost primary basic foodstuff for all kinds of civilization. A water source is a place or container of natural and or artificial water contained above or below the soil surface [1]. The most frequent source of water is spring, an example of ground water source. One of the impacts of modernization is water shortage as demand of water is increasing from time to time.

Water shortage also takes place in Insana, a region located in Timor Tengah Utara (TTU). Causes of the water shortage are shifting cultivation, geographical location and harsh climate, the occurrence of drought on the wells of the community, and the limited surface water resources, make access to clean water is very difficult, encouraging people to take underground water continues to increase [2], so people should take water at springs and streams that are sufficient far or away or people with enough

Correspondence address:

Emanuel M. Y. Hano'e

Email : emanuelmyhanoe@gmail.com

Alamat : Enviromental Resource Management and Development, Postgraduation University of Brawijaya, Malang, Indonesia economy usually buy water during the dry season. Water drought affects the problem of hunger, health as people often suffer from skin diseases, and other diseases. People also buy water when they can afford it. The water shortage results in famine and some health issues, such as skin rash.

Aspects of water resources management consists of water resources conservation aspects[3]. Water source conservation aims to maintain characteristics and function of water source, preserve environment around the water source and make sure there is ample supply of clean water now and in the future.

Important aspect of water source conservation is to engage public, private and public institution's participation in the program [4]. The key to successful water source conservation program is to develop synergy and integrated communication between members of the society. Through the participation of development activities is not just an obligation carried out by the government itself, but also involves community involvement to improve the quality and quality of life [5]. Active participation by the community is the key to the success of conservation. Water source management will benefit both the society and the environment. 


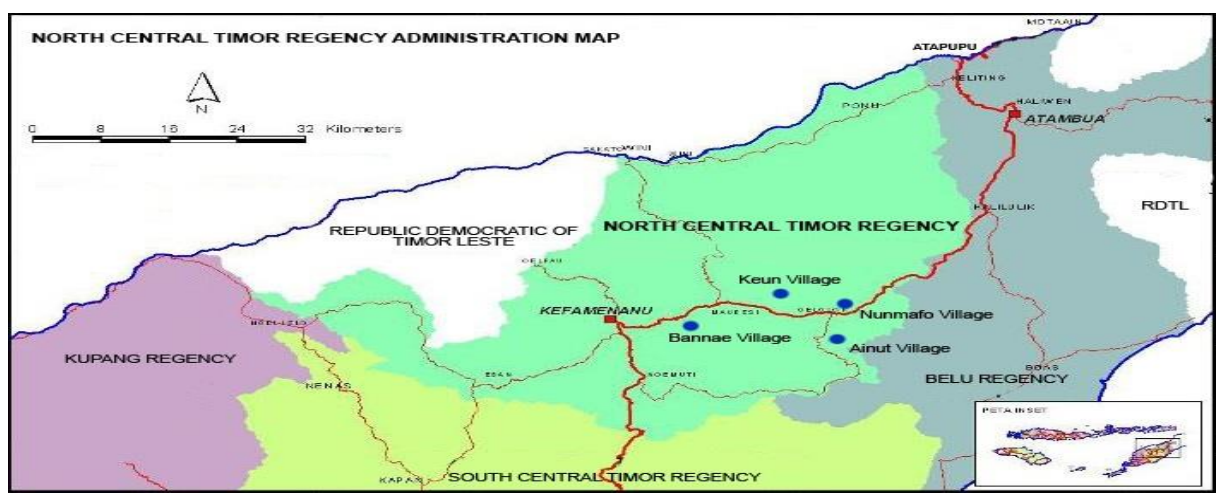

Figure 1. North Central Timor Regency Administration Map

The purposes of the study were to analyze public participation in water source conservation program in Insana region and strategies for public-based water source conservation in the area.

\section{METHODOLOGY}

The study was a descriptive quantitative study. The data collection techniques were observation, interview and documentation. The total samples were 89 respondents. The following formula was used to determine the samples [6]:

$$
\mathrm{n}=\frac{\mathrm{N}}{1+\left(\mathrm{N} \cdot \mathrm{d}^{2}\right)}
$$

Arstein ladder was the data analysis method used to identify public participation, while SWOT analysis was used to develop strategy for publicbased water source conservation.

Objective of SWOT analysis is to identify and develop logic-based strategy by maximizing Strength and Opportunity as well as minimizing Weakness and Threat. Strategic factor is dominant factor from strength, weakness, opportunity and threat that affect existing condition and situation and provide advantage when positive action is taken. The total score was 1 (one), ranging between 1.0 (very important) and 0.0 (not important). The scale for the strategic factor towards its condition was between 4 (very strong) and 1 (weak). The score for the positive variables (strength or opportunity) is between 1 and 4 by making comparison with the average competitor. The score for the negative variables (weakness or threat) is between 1 and 4 (for minor threat or when the threat is lower than that of the average competitor) [7].

\section{RESULT AND DISCUSSIONS}

The study was conducted in Ainiut, Nunmafo, Keun, and Bannae villages in Insana region, Timor Tengah Utara, East Nusa Tenggara between October and November, 2017. The villages were selected as the setting for the study because there was water shortage during certain time in a year in the area.

Geographically, Timor Tengah Utara is located in $9^{\circ} 02^{\prime} 48^{\prime \prime}-9^{\circ} 37^{\prime} 36^{\prime \prime}$ South Latitude and $124^{\circ} 04^{\prime} 02^{\prime \prime}-124^{\circ} 46^{\prime} 00^{\prime \prime}$ East Longitude. The total size of the municipality is $2,669.70 \mathrm{Km}^{2}$ or $5.64 \%$ of the total East Nusa Tenggara area. The topography is between 0 and 2,427 asl.

Timor Tengah Utara consists of 24 regions, 141 villages and 33 sub-regions. Its north borders are Ambenu, Timor Leste and Sawu Sea. Its south border is Timor Tengah Selatan, east border is Belu and west borders are Kupang and Timor Tengah Selatan.

Based on Schmidt and Ferguson's climate classification, Timor Tengah Utara (TTU) is categorized as type $D$ (mild) and the $Q$ coefficient (ratio between average dry months and rainy months) is $71.4 \%$ in which the dry months are more dominant. There were 71 rainy days in 2015 and the rainfall was $1,633 \mathrm{~mm}$. Based on Sap'an Recording Station in Insana region, there were 87 rainy days in 2015 and 49 days in 2016 [8].

Insana is one of the 24 regions in TTU municipality. Its total population is 19,918 people and its total size is $333.08(\mathrm{~km} 2)$. Majority of the locals is farmers. Their agriculture system consists of food corps, plantation, forestry, livestock and fish-farming. In the last three years, shifting agriculture, soil erosion, decreasing level of soil fertility, land slide, decreasing amount of water debit, land coverage, deforestation and lack of skillful human resource have become 
environmental and human resource development issues in the area.

\section{Raw Water Source Service in Timor Tengah Utara}

Perusahan Daerah Air Minum (PDAM) of Kefamenanu is a public responsible for water resource management in TTU and provides clean water for the locals. PDAM of TTU provides clean water for 50,126 people or $20.54 \%$ out of 244,016 people, the total population in TTU (Data, 2015). Based on PDAM technical report, there are 2 (two) IKK, namely IKK Wini and IKK Eban that provides regional clean water service in TTU. PDAM also provides clean water for the following regions, Miomaffo Timur, Miomaffo Barat, Biboki Utara.

Besides PDAM, the locals also take advantage of Bukan Jaringan Perpipaan (BJP) Pedesaan to get clean water. They use well, nearby water sources (spring and surface water) as water sources. Based on the 2016 survey on drinking water need, in 20121, Insana region will need $36.07 \mathrm{l} / \mathrm{dt}$ of raw water while TTU will need $444.41 \mathrm{l} / \mathrm{dt}$ of raw water in the next 5 years (2021) (Regional Development Agency of TTU, 2016).

\section{Characteristics of Locals in Insana Region}

Based on 89 locals from 4 (four) locations in Insana region who became the samples, the characteristics of the society in Insana region are;

\begin{tabular}{llc}
\multicolumn{3}{c}{ Table 1. Characteristics of Locals in Insana Region } \\
\hline $\begin{array}{l}\text { Characteristics } \\
\text { of Community }\end{array}$ & Groups / Category & Result \\
\hline Gender & Male & $41 \%$ \\
\multirow{4}{*}{ Age } & Female & $59 \%$ \\
& $5-20$ years old & $6 \%$ \\
& $21-26$ years old & $13 \%$ \\
$27-30$ years old & $13 \%$ \\
Work & $30-50$ years old & $47 \%$ \\
& $>50$ years old & $21 \%$ \\
& Civil servants & $9 \%$ \\
& Farmers & $50 \%$ \\
& Merchants & $22 \%$ \\
& Student & $16 \%$ \\
Education & Etc & $3 \%$ \\
& Elementary School & $17 \%$ \\
& Junior High School & $28 \%$ \\
& High School & $38 \%$ \\
& University & $17 \%$ \\
& Etc & $0 \%$ \\
\hline
\end{tabular}

Source: Research Results, 2018

\section{Public Participation in Water Source Conservation in Insana Region}

Public participation was evaluated based on how active the public was and how much participation and involvement they had in spreading information about water source conservation or management. Arstein ladder was the instrument used to analyze the public participation [9]. Figure 2 showed the Arstein ladder.

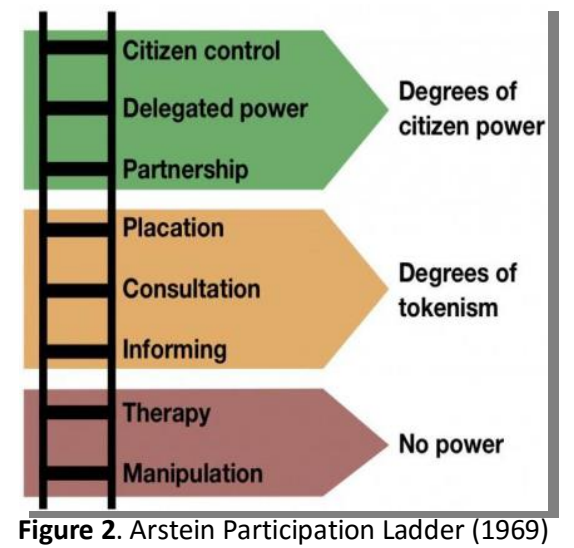

The table 2 described the public participation in the water source conservation program in Insana region.

Table 2. The level of the public-based water source conservation

\begin{tabular}{lc}
\hline \multicolumn{1}{c}{ Indicator } & Skor \\
\hline $\begin{array}{l}\text { Level of community activeness in maintaining } \\
\text { forest area and water source }\end{array}$ & 317 \\
\hline $\begin{array}{l}\text { Participation in consecration work in the } \\
\text { maintenance of water source, pipes, } \\
\text { reservoirs? }\end{array}$ & 301 \\
\hline $\begin{array}{l}\text { Participation community in providing } \\
\text { information related wetlands that occur on the } \\
\text { water source to related parties? }\end{array}$ & 289 \\
\hline $\begin{array}{l}\text { Level of distribution of clean water from water } \\
\text { source? }\end{array}$ & 294 \\
\hline \multicolumn{2}{c}{ Total } \\
\hline \multicolumn{2}{c}{ Categori } \\
\hline
\end{tabular}

Source: Research Results, 2018

The public participation score was 1201 or categorized as "informing." It meant spreading information about rights, responsibility and choice was the first step in asking the locals to participate in the conservation program. Based on the level of information, the level of community participation is marked by attendance without the opportunity to pass judgment.

The provision of information from the government did not have any chance or very little chance for the local people to give their feedback or opportunity to negotiate and give suggestion to the conservation programs (one-way communication between the government and the locals). Information delivery is usually done by participating in the form of pamphlets, brochures, 
announcements through media or periodic reports [10].

Tokenism (negative, diskriminative action), was not prevented. The government invited the locals to participate in the program but had had a set of established plan. At the Degrees of Tokenism level the public is given the opportunity to argue, but there is no guarantee that their proposal will be considered by the government. This participation shows that the role of society is very small in generating a change [10].

\section{SWOT ANALYSIS}

\section{IFAS Matrix (Strength and Weakness)}

The following table described the internal factors of the public-based water source conservation.

Based on the table 3, the score of Strength was 1.23 and that of Weakness was 1.19. On internal factors in the management of water resources that need to be considered related knowledge of the public to the availability of water sources to the utilization. With the availability of natural resources especially the abundant water source and access to accessible water source becomes a capital to meet the needs of the community in the sub-district of Insana.

However, with the availability of water resources, the average community in the subdistrict of Insana with employment as a farmer has a low knowledge of the management and protection of forest areas and springs. Therefore, the management or village government needs to cooperate with relevant agencies or NGOs in strengthening human resources for the Insana community that can improve the spirit and role of the community in the sub-district of Insana in proper management of water resources [11].

Table 3. The internal factors of the public-based water source conservation

\begin{tabular}{|c|c|c|c|}
\hline Strength & Bobot & Rating & Skor \\
\hline Availability of human resources & 0,06 & 3 & 0,19 \\
\hline $\begin{array}{l}\text { The role of the community in } \\
\text { managing the forest area of the } \\
\text { water source }\end{array}$ & 0,06 & 3 & 0,19 \\
\hline $\begin{array}{l}\text { Laws and government policies } \\
\text { related to the conservation of } \\
\text { biological natural resources and } \\
\text { their ecosystems and the } \\
\text { environment }\end{array}$ & 0,06 & 2 & 0,12 \\
\hline Quality and abundant water source & 0,08 & 3 & 0,25 \\
\hline $\begin{array}{l}\text { Water facilities and infrastructure } \\
\text { are available }\end{array}$ & 0,06 & 3 & 0,19 \\
\hline Access to the water source & 0,08 & 4 & 0,3 \\
\hline Total & 0,41 & & 1,23 \\
\hline
\end{tabular}

\begin{tabular}{lccc}
\hline Weakness & Bobot & Rating & Skor \\
\hline $\begin{array}{l}\text { Lack of community and } \\
\text { institutional role towards water }\end{array}$ & 0,07 & 2 & 0,14 \\
source conservation & & & \\
\hline $\begin{array}{l}\text { Lack of regulation / rule of law / } \\
\text { customary law against source area }\end{array}$ & 0,06 & 2 & 0,12 \\
\hline $\begin{array}{l}\text { Management of source that are } \\
\text { less than the maximum }\end{array}$ & 0,07 & 2 & 0,14 \\
\hline $\begin{array}{l}\text { The raw water distribution service } \\
\text { to the community is not good } \\
\text { enough }\end{array}$ & 0,07 & 2 & 0,14 \\
\hline $\begin{array}{l}\text { Lack of human resources in the } \\
\text { application of conservation and } \\
\text { protection of forest areas and } \\
\text { water source }\end{array}$ & 0,08 & 2 & 0,15 \\
\hline $\begin{array}{l}\text { The absence of youth organizations } \\
\text { that care about the environment }\end{array}$ & 0,06 & 2 & 0,12 \\
\hline $\begin{array}{l}\text { The water debit is reduced at a } \\
\text { certain time }\end{array}$ & 0,06 & 2 & 0,11 \\
\hline $\begin{array}{l}\text { Reduced areas of forest around the } \\
\text { water source and zoning areas that } \\
\text { are not clear }\end{array}$ & 0,06 & 2 & 0,12 \\
\hline $\begin{array}{l}\text { Lack of attention to environmental } \\
\text { impacts from changes in forest and } \\
\text { water source }\end{array}$ & 0,07 & 2 & 0,14 \\
\hline \begin{tabular}{l} 
Total \\
\hline
\end{tabular} & $\mathbf{0 , 5 9}$ & $\mathbf{1 , 1 9}$ \\
\hline \begin{tabular}{l} 
Fol score \\
\hline
\end{tabular} & & $\mathbf{2 , 4 2}$ \\
\hline
\end{tabular}

Source: Research Results, 2018

\section{EFAS Matrix (Opportunity and Threat)}

The table 4 showed the internal factors of the public-based water source conservation. Based on the EFAS table 4, the score of Opportunity was 1.58 and that of Threats was 0.94 . People in the subdistrict of Insana want an equitable water supply (distribution) to be able to live their lives so that people do not have the trouble to clean water. Based on external factors (opportunities and threats), the maximum management of water resources will be able to reduce the risk of conflicts among the community, helping the community in Creating and improving the economy of the community and also avoid health problems that can harm the community itself or other threats.

For the management of water sources originating from the spring, the government in this case the village government needs to make improvements in the management, which invites the whole community to participate either in supervision, utilization or in the reforestation of the spring water on the basis of the rules that have been available or the village government needs making village regulations related to water resources management.

Table 4. The external factors of the public-based 
water source conservation

\begin{tabular}{|c|c|c|c|}
\hline Opportunity & Weight & Rating & Skor \\
\hline $\begin{array}{l}\text { Commitment and support of } \\
\text { policy makers on the } \\
\text { sustainability of natural } \\
\text { resources and the } \\
\text { environment }\end{array}$ & 0,1 & 3 & 0,35 \\
\hline $\begin{array}{l}\text { Improve cooperation } \\
\text { between communities }\end{array}$ & 0,1 & 3 & 0,35 \\
\hline $\begin{array}{l}\text { The distribution of water is } \\
\text { stable and evenly distributed }\end{array}$ & 0,09 & 4 & 0,35 \\
\hline $\begin{array}{l}\text { Creating and improving the } \\
\text { agricultural economy of the } \\
\text { community }\end{array}$ & 0,08 & 3 & 0,28 \\
\hline $\begin{array}{l}\text { Development of agricultural } \\
\text { and plantation areas }\end{array}$ & 0,08 & 3 & 0,25 \\
\hline Total & 0,47 & & 1,58 \\
\hline Threat & Weigth & Rating & Skor \\
\hline $\begin{array}{l}\text { The decline in discharge the } \\
\text { well of water causing drought }\end{array}$ & 0,09 & 1 & 0,13 \\
\hline $\begin{array}{l}\text { social conflict community on } \\
\text { the availability of raw water }\end{array}$ & 0,09 & 2 & 0,16 \\
\hline causes health problems & 0,09 & 2 & 0,16 \\
\hline $\begin{array}{l}\text { inhibits the activity of the } \\
\text { community health pose a } \\
\text { problem due to the extinction } \\
\text { of a raw }\end{array}$ & 0,09 & 2 & 0,22 \\
\hline $\begin{array}{l}\text { water source that threatens } \\
\text { plantations forest area }\end{array}$ & 0,08 & 2 & 0,13 \\
\hline illegal logging & 0,08 & 2 & 0,15 \\
\hline Total & 0,53 & & 0,94 \\
\hline Final score & 1 & & 2,51 \\
\hline
\end{tabular}

Source: Research Results, 2018

\section{SWOT Quadrant Analysis (IFAS and EFAS)}

Based on the SWOT analysis, the total score of the Strength and Weakness as the $X$ axis was 0,04 while Table 4 (EFAS) showed that the total score of Opportunity and Threats as the $Y$ axis was 0,06 . Based on the scores, the conservation programs belonged to IB quadrant or (Growth) Stable Growth strategy.

Based on the IFAS and EFAS quadrant (picture $3)$, the public-based water source conservation strategies was classified as (Growth) Stable Growth strategy, in which the strategy is carried out gradually and field observation is conducted to determine targets of the conservation programs.

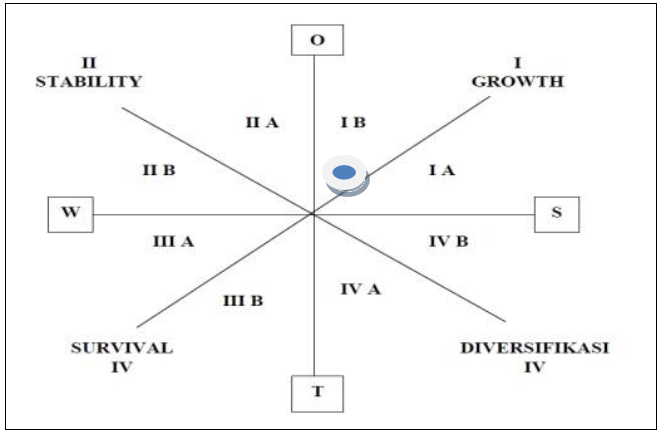

Figure 3. IFAS and EFAS Quadrant Analysis

Strategies to apply in order to carry out the water source conservation program were increasing area for water absorption, improving the water source management, supervision and maintenance, establishing policy on water source conservation, develop channel of communication between members of the society, spreading information on clean water and methods to maintain clean water facilities.

\section{Developing Public-Based Water Source Conservation Strategies}

Based on SWOT analysis, some strategies to apply in order to carry out the water source conservation program were increasing area for water absorption, improving the water source management, supervision and maintenance, establishing policy on water source conservation, develop channel of communication between members of the society, spreading information on clean water and methods to maintain clean water facilities.

\section{The water source conservation}

The water source conservation referred to a set of program of which purposes are to maintain characteristics and function of water source, preserve environment around the water source and make sure there is ample supply of clean water now and in the future. Forest protection management has principles that are consistent with the management of natural resources in sustainable development based on the requirements of forest planning planning that support ecosystem-based forest management. The characteristics of forest-based forest ecosystem planning are; 1) making ecological nature of the fortress as a unity of analysis in determining the needs of the area, 2) integrating the ecological, economic and social interests, 3) the long-term and sustainable specificity, 4) integrating sufficient knowledge with the local 
wisdom through the process of learning which is dynamic, 5) attention to specific characteristics and local interests [12]

Conservation of water resources can be sustained effectively if as part of the surrounding community activities. The management or operation of a conservation area is an attempt to achieve the goal of establishing a conservation area by utilizing all resources owned or which can be utilized with various planned activities. The essence of the management of this conservation area is proces or managed. managed is an interaction between structures, processes and traditions that determine how a decision is made and how others respond [12]. Water source management should focus not only on water utilization but also water sustainaibility and preserving the ecosystem. Supproting factors in water source management program in Insana region were 1 ) youth organizations as medium for public aspiration/ public-hearing, 2) positive local custom, 3) funding for reforestation, 4) awareness on how important clean water is.

\section{Human Resource Development.}

The environmental weaknesses that occur in conservation areas, such as damage to forests, land, biodiversity are often influenced by the availability of human resources both on the part of the government and indigenous peoples, so that the government and society are seriously concerned. Many regions have certain natural resources, but people have not been able to exploit the potentials around them. This happens because the community does not have sufficient knowledge and capacity to manage the resources, either due to low human resources, unchanging mental and other structural constraints, [13].

Damage to the environment around conservation areas, such as deforestation and over-exploitation of natural resources, is influenced by human resources, government or the locals. Therefore, government should pay attention on this issue. Several steps the government may carry out to improve quality of human resource in TTU were: 1) conduct both formal and informal education on conservation, forestry and natural resources, 2) conduct discussion, seminar or workshop on conservation, 3) conduct need analysis in public institutions in TTU and conduct training to meet the need, 4) work together with university or NGO to carry out human resource development program.

\section{Social Conflit Anticipation.}

Poorly managed water source may cause social conflit between locals. Solid management system is the key to avoid this conflict. In managing and reducing the threat to the conservation area Things to be done are; 1 ) create a threat analysis framework, 2) develop a conservation area management plan, 3) participatory conservation management and buffer management, 4) build institutional linkages for local economic development, 5) increase public awareness of conservation area values, 6) develop incentives economy for land use change that reduces threats and improves conservation, 7) develops sustainable long-term financing systems and 8) conducts on going monitoring [14].

\section{Policy Establishment.}

The complexity of natural resource problems requires efforts to solve and anticipate that can not only be done by the government alone but must get the response of all parties either as individuals or groups or legal entities including the legislative element. The problem areas and their solutions should be viewed thoroughly and involve the role of as many related parties as possible. Natural resource management policies and strategies can only be implemented effectively and achieve optimal results if in planning always consist of three considerations, namely: 1) nature and natural characteristics of natural resources it self, 2) technological discipline in the field of natural resources, and 3) society especially related (acceptable or not by society).

Water source management refers to an effort to plan, carry out, supervise, and evaluate water source conservation program, water utilization as well as to minimize water-damaged phenomenon. The principles of conservation and water source facility maintenance guide were applicable in water source management [1].

In the management of water resources the principles of conservation and protection and security of water resources infrastructure can be applied. Water resources are managed comprehensively, integrated, and environmentally sound with respect to the principles of sustainability, balance, general benefit, alignment, harmony, civility, independence, transparency to consume the sustainable use of water resources. In general, 
water resources are the basic capital of national development, social functions, environmental functions and economic functions must be running in harmony for sustainable utilization.

To improve the management and to ensure that the rights of the people are guaranteed, the participation of the community and / or community groups must be involved starting from design planning (planning) including stakeholders in sustainable management of water resources [4].

\section{CONCLUSION}

Based on the Arnstein Ladder, the public participation is categorized as "informing" or oneway communication between the government and the locals. The locals do not have opportunity to give feedback or power to negotiate. Some strategies to apply the public-based water source conservation are 1) conduct conservation program in and around the water source, 2) improve the water resource management system, supervision and maintenance, 3) eliminate social conflict, 4) issue some regulations on conservation areas and water source preservation, and 5) conduct human resource development program for the locals.

\section{ACKNOWLEDGEMENT}

The authors are grateful to the Director and Lecturer of Postgraduate of Brawijaya University as well as the Counselors and Examiners who have provided direction in the refinement of this thesis.

The authors also thank the parents, classmates and to all parties have helped because with the help of this thesis can be resolved properly.

\section{REFERENCES}

[1]. Undang-Undang No. 7 Tahun 2004 tentang Sumber Daya Air. Pemerintah Republik Indonesia. Jakarta

[2]. Adoe, 2008. Pengendalian Pemanfaatan Air Bawah Tanah Di Kota Kupang. Tesis. Program Pascasarjana Magister Teknik Pembangunan Wilayah Dan Kota Universitas Diponegoro. Semarang

[3]. Kodoatie dan Widiarto. 2016. Menjaga Kedaulatan Air. Penerbit Andi. Jogjakarta.

[4]. Rochmah, 2010. Resposivitas Pelayanan. Studi pada Kebijakan Pelayanan Air Bersih. UB Press. Malang
[5]. Mardikanto dan Soebiato, 2017. Pemberdayaan Masyarakat dalam Perspektif Kebijakan Publik. Alfabeta. Bandung

[6]. Darmawan, 2013. Metode Penelitian Kualitatif. Remaja Rosdakarya. Bandung

[7]. Parmawati, Leksono, Yanuwiadi, Kurnianto. 2017. Exploration of Marine Tourism in Watulimo, Trenggalek Regency: Challenges, Potentials, and Development Strategies. Journal of Indonesian Tourism and Development Studies. E-ISSN: 2338-1647. Graduate School of Environmental Sciences, University of Brawijaya, Malang, Indonesia

[8]. BPS Kab TTU 2016. Kabupaten Timor Tengah Utara Dalam Angka. 2016. ISSN: 2356.1017

[9]. Arnstein, Sherry. 1969. A Ladder of Citizen Participation. Journal of the American Institute of Planners.

[10]. Kurniawan, 2015. Partisipasi Masyarakat Dalam Pengelolaan Lingkungan Hidup di Desa Mojokrapak Tembelang Jombang. Tesis. Program Pascasarjana Universitas Brawijaya. Malang

[11]. Prastowo. 2008. Pengelolaan Ekosistem Mata Air. Penyelamatan tanah, air, dan lingkungan. Editor: Sitanala Arsyad dan Ernan Rustiadi. Crestpent Press dan Yayasan Obor Indonesia. Jakarta

[12]. Daryanto dan Suprihatin. 2013. Pengantar Pendidikan Lingkungan Hidup. Gava Media. Jogjakarta

[13]. Hermawan, Faida, Wianti, Marhaento dan Anindia. 2014. Pengelolaan kawasan Konservasi. Gadjha Mada University Press. Jogjakarta

[14]. Susilo, 2012. Sosiologi lingkungan dan Sumber daya Alam: Perspektif Teori \& Isu-isu Mutakhir. A-Ruzz Media. Jogjakarta. 